\title{
Histochemical and Morphological Characteristics of the Levator Ani Muscle in Rats
}

\author{
Características Morfológicas e Histoquímicas del Músculo Elevador del Ano en Ratas
}

"Edna Maria do Carmo; *Tatiana Midori Miyaoka; *Natália Denipoti da Silva; *Marcela Regina de Camargo; "Ana Paula Rodrigues Rocha; "Eliza Bizetti Pelai; *Jéssica Ibde Jaquiel Figueira; "Cristina Elena Prado Teles Fregonesi; ${ }^{* *}$ José Takaiti Sato; ${ }^{* * *}$ Roberto Gameiro de Machado \& ${ }^{* * *}$ Wilson Machado de Souza

DO CARMO, E. M.; MIYAOKA, T. M.; DA SILVA, N. D.; DE CAMARGO, M. R.; ROCHA, A. P. R.; PELAI, E. B.; FIGUEIRA, J. I. J.; FREGONESI, C. E. P. T.; SATO, J. T.; DE MACHADO, R. G. \& DE SOUZA, W. M. Histochemical and morphological characteristics of the levator ani muscle in rats. Int. J. Morphol., 29(4):1195-1201, 2011.

SUMMARY: The current study aimed to analyze the histochemical and morphological characteristics of the levator ani muscle in rats. For this, we used 10 Wistar rats (5 males and 5 females), weighing between 200 and $765 \mathrm{~g}$. The animals were dissected fresh and in formalin for the levator ani muscle anatomical observation. Muscle fragments were collected and frozen in n-Hexane previously cooled in liquid nitrogen. Then, the muscles were transferred to a microtome cryostat (HM 505 E Microm), being fixed in metal mounts with the adhesive Tissue Freezing Medium. Histological sections of $6.0 \mu \mathrm{m}$ were removed and subjected to HE staining. Other sections were subjected to NADH-TR and SDH reactions. After being dissected and fixed, the architecture of the female pelvic floor revealed the presence of two muscles: iliocaudalis and pubocaudalis. The anatomical inspection in male rats revealed, pronouncedly, the presence of the levator ani muscle: ischiocavernosus and bulbocavernous. We therefore observed a marked anatomical difference between animals of the same species, which does not occur with humans. The HE staining revealed muscular fibers with preserved morphology, contours ranging from polygonal to rounded, acidophilic cytoplasm, one or more peripheral nuclei with rounded shape and dense chromatin aspect. The fibers were organized in fascicles arranged by a dense connective tissue, the perimysium, and each fiber surrounded by the endomysium, composed of loose connective tissue. The sections subjected to NADH-TH and SDH, whose reactions show the activity of oxidative or glycolytic muscle fibers, allowed the identification of the two types of fiber. The fast-twitch fiber shows weaker reactivity, whereas the slow-twitch fiber has small diameter and intense reactivity, especially in the subsarcolemmal, presenting a highly oxidative metabolism. It was found that the pelvic floor muscles in rats are composed primarily by fast-twitch fibers, while in humans they are predominantly formed by slow-twitch fibers. Thus, models with these animals and various kinds of protocols for muscular training should be used cautiously.

KEY WORDS: Pelvic floor; Muscle skeletal; Physical therapy; Model animals; Muscle fibers.

\section{INTRODUCTION}

The normal physiological function of the pelvic organs depends on the anatomical integrity of the support components, since defects in pelvic support may contribute to the prolapse of these organs, resulting in urinary and fecal incontinence as well as sexual dysfunction. Therefore, knowing the details concerning anatomic support is essential to diagnose and treat dysfunctions in the pelvic floor (Corton, 2005).

Currently, there are different techniques that propose to train the pelvic floor muscles (PFM) to increase their strength and endurance, and reflexively, induce the closure of the urethral canal, aiming to maintain continence. However, we realize that in such protocols, the metabolic specificity of each muscle is not being considered, nor its structural differences, for choosing the best type of training or other kind of physical therapy practice. (Dumoulin \& HaySmith, 2008; Marques et al., 2010; Piassarolli et al., 2010; Quartly et al., 2010; Börgermann et al., 2010). Thus, we understand the importance for further anatomicalmorphological and histochemical study of this region, in order to improve the focus of disease treatments.

* Departament of Physical Therapy. School of Science and Technology, Sao Paulo State University. Presidente Prudente, SP, Brazil.

** Department of Veterinary Medicine. Sao Paulo Western University. Presidente Prudente, SP, Brazil.

${ }^{* * *}$ Department of Biosciences, Production and Animal Health. School of Veterinary Medicine. Sao Paulo State University. Araçatuba, SP, Brazil.

This study was supported by Fundação de Amparo à Pesquisa do Estado de São Paulo - FAPESP, Process number 05/51207-8 
DO CARMO, E. M.; MIYAOKA, T. M.; DA SILVA, N. D.; DE CAMARGO, M. R.; ROCHA, A. P. R.; PELAI, E. B.; FIGUEIRA, J. I. J.; FREGONESI, C. E. P. T.; SATO, J. T.; DE MACHADO, R. G. \& DE SOUZA, W. M. Histochemical and morphological characteristics of the levator ani muscle in rats. Int. J. Morphol., 29(4):1195-1201, 2011.

The anatomy of the pelvic floor (PF) has been subject to many studies and many inconsistencies in the terminology of the PFM and respective connective tissue are found (Guo \& Li, 2007; Wallner, 2008; García-Armengol et al., 2008; Wang et al., 2010; Weber \& Walter, 1995). In humans, the levator ani muscle (LA) is a complex unit, which consists of several muscular components with different origins and insertions and, therefore, distinct functions. Many nomenclatures have been used to describe the components of the LA, which has generated a series of contradictions (Kerney et al., 2004). However, the FCAT (1998) acknowledges, in anatomic terminology, the pubococcygeus (PC), puborectalis (PR), iliococcygeus (ICc) muscles as part of the LA.

The PC is composed by the puboperineal and puboanal in men (Myers et al., 2000) and puboperineal, puboanal and pubovaginal, in women. The pubovaginal refers to the medial fibers that attach to the side walls of the vagina. The puboperineal comprehends the fibers that attach to the perineal body and round this structure toward the pubic symphysis. Still, the puboanal issues the fibers that attach to the anus in the inter-sphincteric groove, between the internal and external anal sphincters. The PR represents the medial and inferior fibers of the LA, which arise from each side of the pubic bone and form a loop behind the anorectal junction. The ICc, that is the thinnest and posterior part of the levators, arises laterally to the tendinous arch of the LA and the ischial spine and, the muscular fibers from one side join the ones from the opposite side through the iliococcygeal raphe (anococcygeal) and coccyx (Corton; Wallner et al., 2008; Ashton-Miller \& DeLancey, 2007).

Histologically, LA muscle in humans consists of a heterogenic combination of Type I or oxidative fibers (70\%), responsible for the maintenance of the pelvic floor tonus, thus providing support to the pelvic viscera, and of Type II or glycolytic (30\%), activated during the increased intraabdominal pressure (Bourcier et al., 1999; Shafik et al., 2002). In its function, LA differs from most other skeletal muscles for three reasons: keeps constant tone, except during evacuation and Valsalva maneuver; shrinks rapidly, at the time of acute stress, in order to maintain continence; distends considerably during labor, shrinking again eventually, to restore physiological functioning (Wall, 1993; Sumino et al., 2006; Moalli et al., 2005; Pierce et al., 2007).

Currently, rats are the most used animal model to investigate prolapsed pelvic organs and urinary and fecal incontinence. The morphology of the pelvic conjunctive tissue in female rats is similar to humans: the rectouterine ligaments originate in the superior part of the vagina and fix in the inferior segment of the spine (Abramowitch et al.,
2009; Moalli et al.). However, the muscle anatomy has some differences in these animals. Bremer et al. (2003) performed dissection of the pelvic cavity of rats and described the iliocaudalis muscle (ICa), originated in the ilium and inserted in the caudal vertebrae (Ca) $\mathrm{Ca} 5-\mathrm{Ca} 6$ and the pubocaudalis muscle $(\mathrm{PCa})$, originated in the pubis and inserted in the $\mathrm{Ca} 3-\mathrm{Ca} 4$.

Apparently the LA function is also different from human, for its primary part is to support the tail, while the conjunctive tissue annexes serve as a vaginal support. Supporting this difference, Poortmans \& Wyndaele (1988) dissected and observed the tail and bowel movements of the rats, measuring the vagina, rectum and urethra pressure during electrical stimulation. The LA stimulation led only to an insignificant increase in pressure in the rectum and no elevation of this or the anus. Also by means of electrical stimulation, though in humans, Shafik \& El-Sibai (2001) found that the LA contraction lowered the anal and urethral pressure, helping the evacuation process. This findings support the concept that there really is difference in the LA function, between rats and humans.

Besides, some authors agree that, in addition to the idea above, the apparent differences in size, biped or quadruped posture, and fetus dimension during pregnancy, suggest that the mechanism of development and evolution of the prolapsed and incontinence, in women, possibly, are not the same as in female rats. Nevertheless, such animal model may provide information about changes that contribute to the emergence and pathophysiology of the prolapsed pelvic organs (Abramowitch et al.; Moalli et al.).

In this light, we perceive the need to improve the knowledge of the PFM, in order to better understand the pathophysiology of diseases of the PF. Therefore, this study aimed to identify the anatomical and morphological and histochemical profile of rats PFM, specifically the LA, and discuss the differences between genera and species.

\section{MATERIAL AND METHOD}

Animals. We used 10 Wistar rats (5 male and 5 female) provided by the Laboratory of Morphological Anatomy, School of Dentistry, Sao Paulo University (FOA/UNESP), Araçatuba, SP, Brazil, weighing from 200 to $765 \mathrm{~g}$. The animals were kept in the Laboratory of Animal Stress Physiology, School of Sciences and Technology (FCT/ UNESP), Presidente Prudente, SP, Brazil, in collective plastic cages $(0.30 \times 0.16 \times 0.19 \mathrm{~m})$, maximum 5 animals per cage. These animals remain in the vivarium (under average 
temperature $22 \pm 2.0^{\circ} \mathrm{C}$, in a dark/bright cycle of 12 hours, starting the bright cycle at 7 a.m.) by, at least one week before being used. We offered standardized rations and water $a d$ libitum.

The experimental protocol was approved by the Ethical Commission of the Research in Sao Paulo Western University - UNOESTE, according to resolution 196/96 of the Brazilian Health National Council (October 10th, 1996) and Ethical Principles for Animal Experimentation prepared by Brazilian College of Animal Experimentation (COBEA), with protocol number 001/05.

Dissection of the LA muscle. For comparison, we chose to apply a dose of $10 \mathrm{~mL}$ of formaldehyde $10 \%$, in two animals (one male and one female) in the 24 hours prior to the procedure. The others were dissected fresh. The dissection was performed through a ventral midline incision to the pubic region, performing a folding of the skin to expose the muscles of the perianal region. Only after the identification of the fresh PFM in both genders, photographic documentation was conducted.

The experiment was performed in two different occasions and locations. The animals subjected to formaldehyde and two of the animals dissected fresh (a male and a female) were analyzed at the Laboratory of Stress Physiology of the FCT/UNESP. The remaining animals dissected fresh were analyzed at the Laboratory of Morphological Anatomy of the FOA/UNESP.

Morphological Analysis. The morphological evaluation of the muscles was performed at the Laboratory of Histology, FCT/UNESP. Muscle fragments were collected and frozen in $\mathrm{n}-\mathrm{Hexane}$ previously cooled in liquid nitrogen from 1.0 to 2.0 minutes. Then, the muscles were transferred to the chamber of a microtome cryostat (HM 505 E Microm) ($20^{\circ} \mathrm{C}$ ), fixed in metal mounts, with the adhesive Tissue Freezing Medium. Histological sections of $6.0 \mu \mathrm{m}$ were removed and subjected to hematoxylin-eosin staining (HE).

Other sections were subjected to Nicotinamide Adenine Dinucleotide-Tetrazolium Reductase (NADH-TR) and Succinate Dehydrogenase $(\mathrm{SDH})$ reactions in the Laboratory of Histochemistry, Department of Morphology, Institute of Bioscience (IB/UNESP), Botucatu, São Paulo, Brazil.

These reactions show the oxidative or glycolytic activity of the muscle fibers. The flavoenzyme NADH-TR, also called diaphorase, oxidizes the NADH and is present both in the mitochondria and the sarcoplasmic reticulum. The NADH-TR enzyme captures the hydrogen electron and transfers it to an acceptor, a tetrazolium salt (NBT). As a result, deposits of formazan are observed (dark blue coloration) in areas of higher intensity of oxidative activity. The SDH enzyme, present in the mitochondria, removes the electron from the succinate which is transferred to the NBT which, in turn, is reduced to form the formanzan (Dubowitz \& Brooke, 1973; Louglin, 1992).

Images Documentation. The images of HE staining, and the SDH and NADH reactions were acquired in the department of Physics, Chemistry and Biology of FCT/ UNESP. They were obtained from an image scanning system, SDI, which consists of a Leica DMRX microscope with magnification of 20x/100 and 50x/100 in the objectives and $10 \mathrm{x} / 100$ in ocular and a computer, coupled to a digitalizing camera (ExwaveHAD; Sony, Model SSC-DC54A). Additional images were obtained from the Laboratory of Morphological Anatomy FOA/UNESP. To this end, a Sony Model DXC-950P 3CCD was used, coupled to a system Leica Q550IW image analyzer.

\section{RESULTS}

After being dissected and fixed in formalin and fresh, the female PFM revealed the presence of two muscles: the $\mathrm{ICa}$ and the PCa. It was also noticed that in the female rats, the $\mathrm{ICa}$ and the $\mathrm{PCa}$ were located below the pubic symphysis (Fig. 1), with the ICa originating in the ilium. Both muscles have tendons that attach directly to the caudal vertebrae, being the Ica subdivided into three portions: proximal, medial and distal.

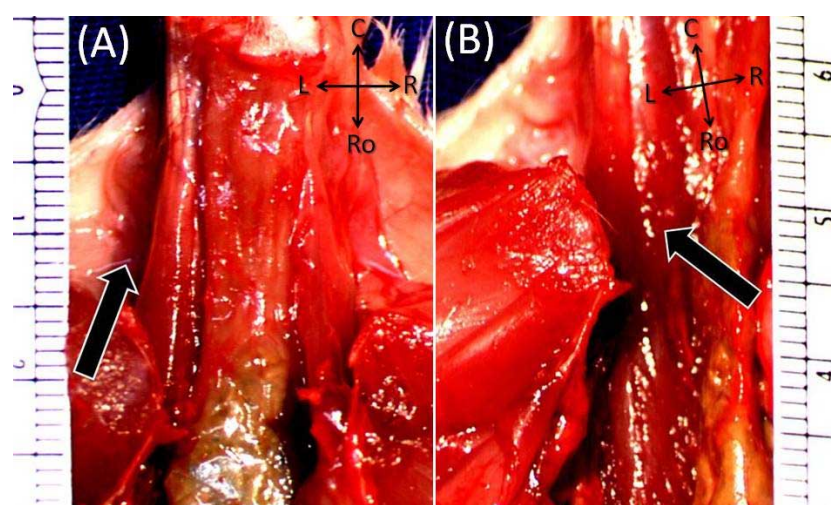

Fig. 1. Anatomy of female rat pelvic floor. Arrows: (A): Pubocaudalis Muscle. (B): Iliocaudalis Muscle. C: Caudal Ro: Rostral; R: Right; L: Left.

The anatomical inspection in males showed, pronouncedly, the presence of LA, ischiocavernosus (IC) and bulbocavernosus (BC) (Fig. 2). The LA in male rats 
evolves the rectum, external to the pubic symphysis. Thus, morphologically, in female rats, the LA consists of the ICa and PCa muscles. In male rats, the LA is a single muscle, which surrounds the rectum and is macroscopically visible.

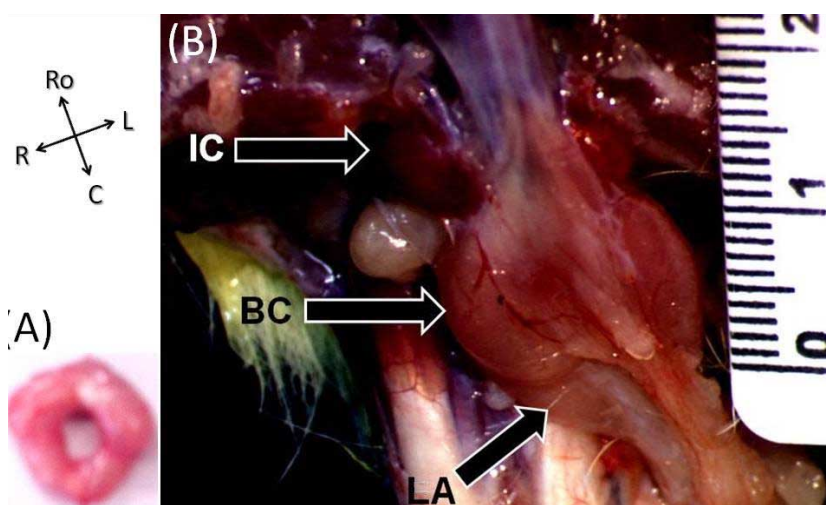

Fig. 2. Anatomy of the pelvic floor in male rat. (A): Levator Ani. (B): Muscles: Ischiocavernosus (IC); Bulbocavernous (BC) and Levator Ani (EA). C: Caudal Ro: Rostral; R: Right; L: Left.

The HE staining of the ICa, PCa and LA muscles in cross sections to the major axis of the LA in animals, showed muscular fibers with preserved morphology, contour ranging from polygonal to round, acidophilic cytoplasm, one pre more peripheral nuclei, round-shaped and chromatin denselooking, stained with hematoxylin, as it is basophilic. The fibers were arranged in fascicles delimited by dense connective tissue, the perimysium, and each fiber surrounded by the endomysium, consisting of loose connective tissue (Fig. 3).
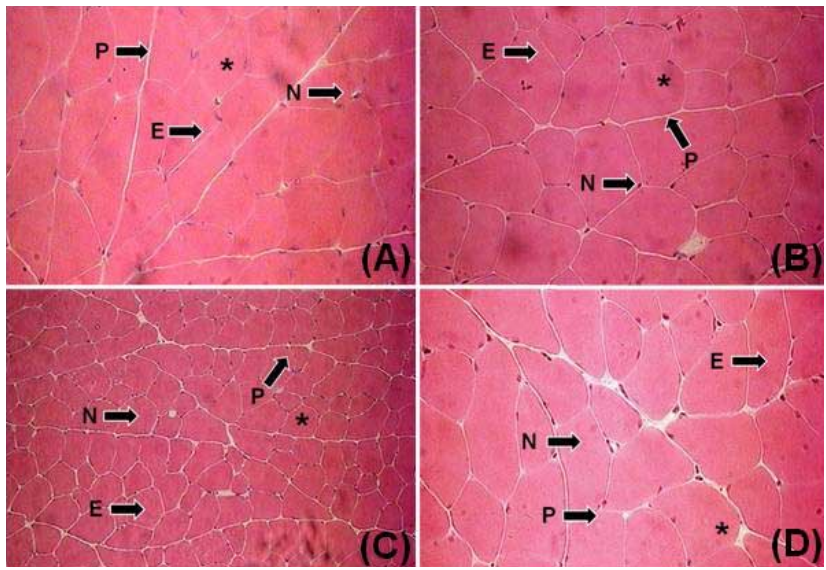

Fig. 3. Histological sections of the transversal axis of the Levator Ani, stained with hematoxylin-eosin. (A): Levator Ani muscle in male rats $(50 \mathrm{x})$; (B) and (C): Iliocaudalis muscle in female rats (50x); (D): Pubocaudalis muscle in female rats (50x). (*) Normal Aspect; (E): Endomysium; (N): Periferal Nuclei; (P): Perimysium.
After the completion of the reactions NADH-TR and $\mathrm{SDH}$, which reveal the metabolism, two types of fibers were identified in the ICa, PCa and LA muscles: fibers with small diameter and intense NADH-TR and SHD reactivity (oxidative metabolism) and fibers with weak enzymatic activity (glycolytic metabolism) (Figs. 4 and 5).

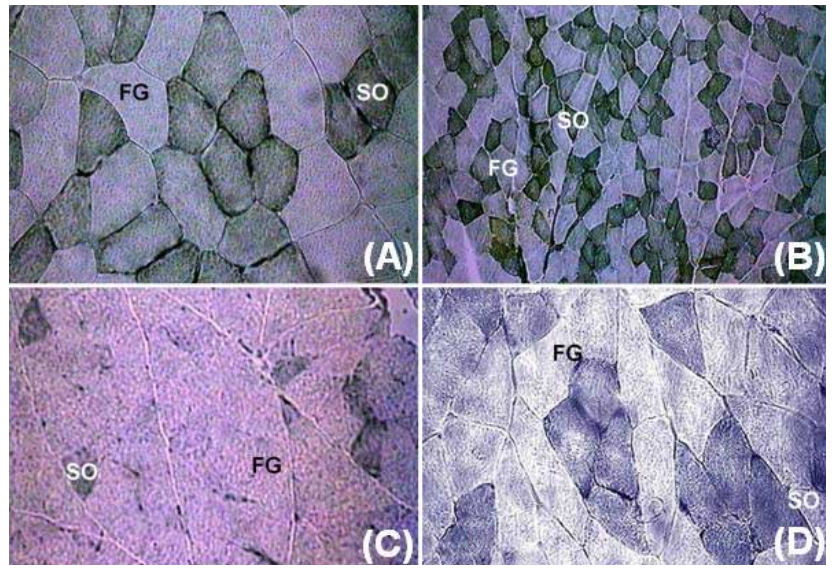

Fig. 4. Histological sections of the transversal axis of the Levator Ani, underwent the reaction Nicotinamide Adenine Dinucleotide Tetrazolium Reductase (NADH-TR). (A) and (B): Iliocaudal muscle in female rats (50x and 20x, respectively) ; (C): Levator Ani muscle in male rats (50x); (D): Pubocaudal muscle in female rats (50x). (FG): Glycolytic Fibers; (SO): Oxidative Fibers.

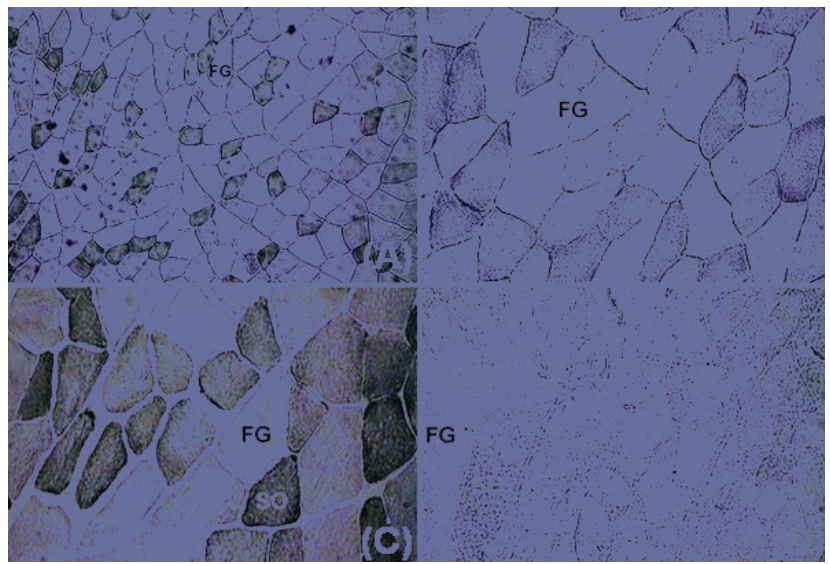

Fig. 5. Histological sections of the transversal axis of the Levator Ani, subjected to the reaction Succinate Dehydrogenase (SDH). (A) and (C): Iliocaudal muscle in female rats (20x and 50x, respectively); (B): Pubocaudal muscle in female rats (50x); (D): Levator Ani muscle in male rats (50x). (FG): Glycolytic Fibers; (SO): Oxidative Fibers.

\section{DISCUSSION}

In humans, the PFMs consist of the LA and the coccygeus muscles. The main subdivisions of the LA are the muscles PC; PR and ICc, in a "U" shape arrangement, 
outlining the rectum, which contains the urethra (in men) and the urethra and vagina (in women) (Corton). With the present results it was possible to note that, in rats, the LA is uniform, with no subdivisions and embraces the rectum in a circular or "O" shape.

These findings support the ones by Poortmans \& Wyndaele and according to which the LA of these animal show gross anatomical similarity to the PR in humans. Both muscles can be seen bilaterally, connected through a dorsal raphe nucleus and both surround the rectum, without strong attachments to the coccyx. However, their origins are distinct, while the PR is fixed on both sides of the pubic symphysis, the LA in rats is linked to the bulbocavernous urethral body.

In females, there was the presence of the ICa and the $\mathrm{PCa}$, located posterior to the pubic symphysis. These muscles have some similarities to the correspondent muscles in humans, such as volume and tendon attachments. However, as to the form, they are different: while in humans the PC is rectangular and the $\mathrm{ICc}$ is protuberant, in female rats, both are triangular (Poortmans \& Wyndaele). Thus, it is understood that in female, the LA is not a single unit, consisted of the ICa and $\mathrm{PCa}$, which are also part of the complex LA in humans, according to observations by Tobin \& Joulbert (1988). The striking anatomical difference between animals of the same species was an important finding in this study. Such fact was responsible for great distress in dissection, since the anatomical models describing, minutely, the pelvis of the female rats are scarce.

The role of muscles and pelvic structures in the maintenance of urinary continence may vary between different species. Some factors must be taken into account such as the size of the animal, the biped or quadruped posture and the life style (frequency of voiding, flow speed and others). In order to be an effective muscular training, besides the aforementioned characteristics, it is necessary to understand the muscle fibers metabolism, in order to determine whether the expected result will come with strength training, endurance or both (Fitts \& Widrick, 1996; Minamoto, 2005; Rosa et al., 2007).

Through histochemical techniques, the existence of fast and slow twitch in the PCa and ICa muscles was proven in female rats and in the LA in male rats. In muscle staining, the preservation of the bundles of muscle fibers was observed and the two types of contractile fibers could be identified. Therefore, the LA of rats, in both genders, contain muscle fibers of glycolytic (more present) and oxidative metabolism.

Bø et al. (1999) observed that the exercises are more effective than other treatments for stress incontinence. It is known that the efficiency of muscle training is based in three principles: overload (with muscular work above the usual), specificity (with muscular activity very close to the necessary movements) and reversibility (incorporating the exercises into the routine of the individuals) (Marques et al.). Although some studies describe the use of several treatment protocols in the prolapse of the PF, little is said in the scientific literature, on the modality training adopted. Thus, the histological analysis on the profile of muscle fibers in this region is useful to focus on the type of fiber to be trained and/or conditioned.

In humans, the LA consists predominantly of slow twitch fibers (Bouorcier et al..; Shafik et al.) and, according to this study, in rats, fast twitch fibers are more present. Maybe this happens because of the positioning of the pelvic organs and the type of biped $\mathrm{x}$ quadruped posture between different species.

For these reasons, models with Wistar rats may be used, cautiously, to monitor the effectiveness of different training protocols (strength and/or muscle endurance), once its anatomical similarity and function are still being discussed in literature. It is suggested, for instance, doing studies using different electrical stimulation parameters on the LA of these animals and further histochemical analysis of changes in its contractile and metabolic properties.

DO CARMO, E. M.; MIYAOKA, T. M.; DA SILVA, N. D.; DE CAMARGO, M. R.; ROCHA, A. P. R.; PELAI, E. B.; FIGUEIRA, J. I. J.; FREGONESI, C. E. P. T.; SATO, J. T.; DE MACHADO, R. G. \& DE SOUZA, W. M. Características morfológicas e histoquímicas del músculo elevador del ano en ratas. Int. J. Morphol., 29(4):1195-1201, 2011.

RESUMEN: El estudio tuvo como objetivo analizar las características histoquímicas y morfológicas del músculo elevador del ano en ratas. Para esto, se utilizaron 10 ratas Wistar (5 machos y 5 hembras), con un peso entre 200 y $765 \mathrm{~g}$. Los animales fueron disecados frescos y en formol para la observación anatómica del músculo elevador del ano. Fragmentos de músculo fueron recogidos y congelados en n-Hexano, previamente enfriado en nitrógeno líquido. Luego, los músculos fueron trasladados a un micrótomo criostato (Microm HM 505 E), fijados en soportes metálicos con adhesivo Tissue Freezing Medium. Cortes histológicos de $6,0 \mu \mathrm{m}$ fueron retirados y sometidos a tinción de H-E. Otras secciones fueron sometidas a las reacciones de NADH-TR y SDH. Después de haber sido disecado y fijado, la arquitectura del suelo de la pelvis de las ratas hembra, reveló la presencia de dos músculos: m. iliocaudalis y m. pubocaudalis. La inspección anatómica de las ratas macho mostró, marcadamente, la presencia del músculo elevador del ano: isquiocavernoso y bulbocavernoso. Por lo tanto, observamos una marcada diferencia anatómica entre los animales 
de la misma especie, lo que no ocurre con los seres humanos. La tinción HE reveló fibras musculares con morfología conservada, contornos que van desde el esquema poligonal al redondeado, citoplasma acidófilo, uno o más núcleos periféricos con forma redondeada y un aspecto denso de la cromatina. Las fibras se organizaban en fascículos compuestos por un tejido conectivo denso, perimisio, y cada fibra rodeada por el endomisio compuesto por tejido conectivo laxo. En las secciones sometidas a NADH-TH y $\mathrm{SDH}$, cuyas reacciones muestran la actividad oxidativa o glicolítica de las fibras musculares, permitió la identificación de los dos tipos de fibras. Las fibras de contracción rápida muestran más débil reactividad y, las de contracción lenta tienen un diámetro pequeño y reactividad intensa, especialmente en las regiones subsarcolemales, presentando un metabolismo altamente oxidativo. Se encontró que los músculos del suelo pélvico en las ratas están compuestos principalmente por fibras de contracción rápida, mientras que en los seres humanos, son en su mayoría, formadas por fibras de contracción lenta. Así, los modelos con estos animales y diversos tipos de protocolos de entrenamiento muscular deben ser utilizados con precaución.

PALABRAS CLAVE: Suelo pélvico; Músculo esquelético; Terapia física; Modelos animales; Fibras musculares.

\section{REFERENCES}

Abramowitch, S. D.; Feola, A.; Jallah, Z. \& Moalli, P.A. Tissue mechanics, animal models, and pelvic organ prolapse: a review. Eur. J. Obstet. Gynecol. Reprod. Biol., 144(suppl.1):S146-58, 2009.

Ashton-Miller, J. A. \& DeLancey, J. O. Functional anatomy of the female pelvic floor. Ann. N.Y. Acad. Sci., 1101:266-96, 2007.

Bø, K.; Talseh, T. \& Holme, I. Single blind, randomized controlled trial of pelvic floor exercises, electrical stimulation, vaginal cones, and no treatment in management of genuine stress incontinence in women. BMJ, 318(7182):487-93, 1999.

Börgermann, C.; Kaufmann, A.; Sperling, H.; Stöhrer, M. \& Rübben, $\mathrm{H}$. The treatment of stress incontinence in men. Dtsch. Arztebl. Int., 107(27):484-91, 2010.

Bourcier, A. P.; Bonde, B. \& Haab, F. Functional assessment of the pelvic floor muscles. In: Appell, R.A.; Bourcier, A.P. \& LaTorre, F. (Eds.) Pelvic floor disfunction - Investigation \& conservative treatment. Rome, Casa Editrice Scientifica Internazionale, 1999. p.97-106.

Bremer, R. E.; Barber, M. D.; Coates, K. W.; Dolber, P. C. \& Thor, K. B. Innervation of the levator ani and coccygeus muscles of the female rat. Anat. Rec. A Discov. Mol. Cell. Evol. Biol., 275(1):1031-41, 2003.

Corton, M. M. Anatomy of the pelvis: how the pelvis is built for support. Clin. Obstet. Gynecol., 48(3):611-26, 2005.
Dubowitz, V. \& Brooke M. H. Muscle biopsy: a modern approach. London, W.B. Saunders, 1973.

Dumoulin, C. \& Hay-Smith, J. Pelvic floor muscle training versus no treatment for urinary incontinence in women. A Cochrane systematic review. Eur. J. Phys. Rehabil. Med., 44(1):47-63, 2008.

FCAT (Federative Committee on Anatomical Terminology). Terminologia Anatomica, Stuttgart, Georg Thieme Verlag, 1998.

Fitts, R. H. \& Widrick, J. J. Muscle mechanics: adaptations with exercise training. Exerc. Sport Sci. Rev., 24(1):427-73, 1996.

García-Armengol, J.; García-Botello, S.; Martinez-Soriano, F.; Roig, J. V. \& Lledo, S. Review of the anatomic concepts in relation to the retrorectal space and endopelvic fascia: Waldeyer's fascia and the rectosacral fascia. Colorectal Dis., 10(3):298-302, 2008

Guo, M. \& Li, D. Pelvic floor images: anatomy of the levator ani muscle. Dis. Colon Rectum, 50(10):1647-55, 2007.

Kearney, R.; Sawhney, R. \& DeLancey, J. O. L. Levator ani muscle anatomy evaluated by origin insertion pairs. Obstet. Gynecol., 104(1):168-73, 2004

Louglin, M. Muscle biopsy: a laboratory investigation. London, Butterworth-Heinmann, 1992.

Marques, A.; Stothers, L. \& Macnab, A. The status of pelvic floor muscle training for women. Can. Urol. Assoc. J., 4(6):41924, 2010 .

Minamoto, V. B. Classifcation and adaptations of muscle fibers: a review. Fisiot. Pesqui., 12(3):50-5, 2005.

Moalli, P. A.; Howden, N. S.; Lowder, J. L.; Navarro, J.; Debes, K. M.; Abramowitch, S. D. \& Woo, S. L. A rat model to study the structural properties of the vagina and its supportive tissues. Am. J. Obstet. Gynecol., 192(1):80-8, 2005.

Myers, R. B.; Cahill, D. R.; Kay, P. A.; Camp, J. J.; Devine, R. M.; King, B. F. \& Engen, D. E. Puboperineales: muscular boundaries of the male urogenital hiatus in $3 \mathrm{D}$ magnetic resonance imaging. J. Urol., 164(4):1412-5, 2000.

Piassarolli, V. P.; Hardy, E.; Andrade, N. F.; Ferreira, N. O. \& Osis, M. J. Pelvic floor muscle training in female sexual dysfunctions. Rev. Bras. Ginecol. Obstet., 32(5):234-40, 2010.

Pierce, L. M.; Baumann, S.; Rankin, M. R.; Wasserman, R. M.; Biaggi, A.; Kuehl, T. J. \& Coates, K. W. Levator ani muscle and connective tissue changes associated with pelvic organ prolapsed, parity, and aging in squirrel monkey: a histologic study. Am. J. Obstet. Gynecol., 197(1):60.e1-9, 2007. 
DO CARMO, E. M.; MIYAOKA, T. M.; DA SILVA, N. D.; DE CAMARGO, M. R.; ROCHA, A. P. R.; PELAI, E. B.; FIGUEIRA, J. I. J.; FREGONESI, C. E. P. T.; SATO, J. T.; DE MACHADO, R. G. \& DE SOUZA, W. M. Histochemical and morphological characteristics of the levator ani muscle in rats. Int. J. Morphol., 29(4):1195-1201, 2011.

Poortmans, A. \& Wyndaele, J. J. M. levator ani in the rat: does it really lift the anus? Anat. Rec., 251(1):20-7, 1998.

Quartly, E.; Hallam, T.; Kilbreath, S. \& Refshaug, K. Strength and endurance of the pelvic floor muscles in continent women: an observational study. Physiotherapy, 96(4):311-6, 2010.

Rosa, M. J. A.; Dal Pai, V.; Bremer Neto, H.; Azoubel, R. \& Nouailhetas, V. L. A. Effect of swimming training on the rectus abdominis muscle of rats: morphological and histochemical aspects. Int. J. Morphol., 25(3):631-8, 2007.

Shafik A.; Asaad, S. \& Doss, S. The histomorphologic structure of the levator ani muscle and its functional significance. Int. Urogynecol. J. Pelvic Floor Dysfunct., 13(2):116-24, 2002.

Shafik, A. \& El-Sibai, O. Effect of levator ani muscle contraction on urethrovesical and anorectal pressures and role of the muscle in urination and defecation. Urology, 58(2):193-7, 2001.

Sumino, Y.; Sato, F.; Kumamoto, T. \& Mimata, H. Striated muscle fiber compositions of human male urethral rhabdosphincter and levator ani. J. Urol., 175(4):1417-21, 2006.

Tobin, C. \& Joubert, Y. The m. levator ani of the female rat: a suitable model for studying the effect of testosterone on the development of mammalian muscles. Biol. Struct. Morphol., 1(1):28-33, 1988.

Wall, L. L. The muscles of the pelvic floor. Clin. Obstet. Gynecol., 36(4):910-25, 1993

Wallner, C. Is the puborectalis muscle part of the levator ani muscle? Dis. Colon Rectum, 51(7):1165- 6, 2008.

Wallner, C.; Dabhoiwala, N. F.; DeRuiter, M. C. \& Lamers, W. H. The anatomical components of urinary continence. Eur. Urol., 55(4):932-43, 2008

Wang, G. J.; Gao, C. F.; Wei, D.; Wang, C. \& Meng, W. J. Anatomy of the lateral ligaments of the rectum: a controversial point of view. World J. Gastroenterol., 16(43):5411-5, 2010.

Weber, A. M. \& Walter, M. D. What is a vaginal fascia? AUGS Quart. Rep., 13, 1995.

\section{Correspondence to:}

Dra. Edna Mario do Carmo

Departament of Physical Therapy

School of Sciences and Technology

São Paulo State University

Rua Roberto Simonsen n 305

Presidente Prudente, São Paulo

BRAZIL

Email: edna@fct.unesp.br

Received: 14-06-2011

Accepted: 05-09-2011 